\author{
TOMASZ BABNIS (D) \\ JAGIELLONIAN UNIVERSITY, KRAKÓW
}

\title{
ONCE AGAIN ON CLAUDIAN'S EGYPTIAN ORIGIN
}

\begin{abstract}
The life of Claudius Claudian (c. 370 - c. 404 AD), the great Latin poet active during the reign of Honorius, is unknown, especially the years before his great debut in 395 AD. Communis opinio holds that he was a pagan Egyptian Greek born in Alexandria c. 370 AD, who having come to Italy in 394 AD started a career of a political poet in the service of the elites of the Western Roman Empire. This view codified by Alan Cameron (1970) was challenged by Peder G. Christiansen (1997), who asserted that Claudian was actually a Westerner. The thesis of the poet's Egyptian origin was defended by Bret Mulligan (2007) and then again attacked by Peder G. Christiansen and David Christiansen (2009). This article aims to reconsider the scarce textual evidence and to put an emphasis on some points that have been underestimated so far: the possibility of Claudian's early connections with Constantinople and the ruling circles of the eastern capital.
\end{abstract}

KEY WORDS: Claudian, Late Antiquity, Latin in Egypt, vitae poetarum

The poetry of Claudius Claudian (c. 370 - c. 404 AD) is usually considered one of the greatest achievements of Late Antique Latin poetry. Over the past five decades, after the publication of Alan Cameron's seminal monograph in 1970, scholarly interest in his poetry has grown considerably, giving rise to a number of important publications. ${ }^{1}$ However, the

See e.g. Schmidt 1976; Döpp 1980; Long 1996; Ehlers, Felgentreu, Wheeler (eds.) 2004; Garambois-Vasquez 2007; Schindler 2009; Guipponi-Gineste 2010; Ware 2012; Berlincourt, Milić, Nelis (eds.) 2016; Coombe 2018. 
issue of Claudian's descent and religion has been raised relatively rarely among this scholarship. Generally speaking, the majority of works on Claudian begins from the reference to the communis opinio according to which he was a pagan Egyptian Greek born in Alexandria c. 370 AD, and having come to Italy in $394 \mathrm{AD}$ he started a career of a political poet connected with the elites of the Western Roman Empire ${ }^{2}$. In virtually every book on this topic Claudian's life before 394 AD is mentioned in a concise way without investigating the details. However, all of this reconstruction is based on several frequently out-of-context pieces of information drawn from different sources written within the space of a few hundred years. Furthermore, medieval manuscripts have preserved some other tradition concerning Claudian's origin and although none of them was widely accepted, the mere fact of the confusion about this issue shows that the problem needs a thorough investigation. This article aims to reconsider the scarce textual evidence and address some points that have been underestimated so far.

First of all, one should recall the sources referring to the life of the poet, starting from the external evidence and then proceeding to the internal one; both are few and far between. The most trustworthy of them all is surely the bilingual inscription found in the Trajan Forum (CIL VI 1710) praising him - in Greek distich - as a successor of Homer and Vergil. Admittedly, the Greek verse does not have to be tantamount to Greek origin of the honorand but it would seem strange to put it there without any reason, especially in the context of the waning knowledge of Greek in the West. ${ }^{3}$ More or less contemporary statements of St. Augustine (a Christi nomine alienus - Aug. De civ. Dei V 26) and his pupil Paulus Orosius (poeta quidem eximius sed paganus pervicacissimus Oros. Adv. Pag. VII 35, 21) focus on his religion not on his descent. In this respect, it is worth noting that Augustine did not say explicitly that Claudian was a pagan, ${ }^{4}$ whereas Orosius, probably expanding on his

2 Fargues 1933: 5-9; Cameron 1970: 2-3; Cytowska, Szelest 1992: 518; von Albrecht 1997: 1337; Garambois-Vasquez 2007: 7; Schindler 2009: 59; Ware 2012: 5; Coombe 2018: 7-9. Other examples were collected by Mulligan (2007: 287, n. 10).

3 It has been suggested that this distich was written by Claudian himself - Wheeler 2007: 118.

$4 \quad$ We must take at least five options into consideration. The phrase a Christi nomine alienus could mean: 1) a pagan; 2) a heretic; 3) a lukewarm Christian; 4) a poet not 
opinion, put it in a more unequivocal way. The somewhat later author, Sidonius Apollinaris, in his catalogue of poets mentions Claudian's connection to Egypt (Pelusiaco satus Canopo - Sid. Carm. IX 274), which is a clear-cut allusion to Lucan's phrase (et Pelusiaci barbari turba Canopi - Luc. VIII 543). John the Lydian, living in the $6^{\text {th }}$ century, calls

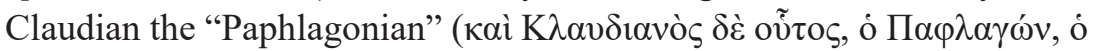
$\pi$ oin $\tau$ '́ - Lyd. De Mag. I 47), which seem to be an insult rather than an ethnic term. ${ }^{5}$ Liber Suda (s.v. Klaudianos) calls him a poet from Alexandria active in the days of Arcadius and Honorius. This source, although compiled in the $9^{\text {th }}$ century, is surely based on earlier works, as regards this entry - probably on the lexicon of Hesychius of Miletus ( $6^{\text {th }}$ century). Admittedly, Suda does not mention this Claudian's Latin poetry or his activities in the Western Roman Empire and we know of some other (probably later) authors bearing the same name, but none of them was his equal, so it would seem strange to see in this entry a reference to another epic poet Claudian who lived in the same time and is otherwise unknown.

As regards internal evidence, the majority of relevant passages come not from Claudian's public poetry but from his carmina minora. Three of them are particularly important. In his short letter to Gennadius ${ }^{6}$ he states: Graiorum populis et nostro cognite Nilo (Claud. c.m. XIX 3), creating the impression of a common Egyptian origin with the addressee. In his poem to Hadrianus he again brings up the common Egyptian descent:

raising Christian topics in his poetry; 5) a poet excessively using pagan imagery in his works. Claudian did not mention Christianity in his public poems, although Christian motifs are present in his carmina minora (esp. in c.m. XXXII). It leads to the problem of their authenticity: scholars considering the poet a pagan treat them as spurious, and those regarding him as a Christian treat them as genuine. Obviously, writing on that topics cannot be truly seen as a watertight argument in terms of his religion, so in the present state of knowledge this problem seems to be insoluble. On Claudian's religion see e.g. Fargues 1933: 153-172; Cameron 1970: 189-227; Döpp 1980: 24-41; Vanderspoel 1986; Moreschini 2004.

5 According to Jacques Schamp (2001), the term "Paphlagonian" should be read as an erudite literary equivalent to "Egyptian".

6 One should bear in mind that the addressees of Claudian's carmina minora are usually not known for sure. Their names come from lemmata in manuscripts and can be wrong, since usually these names are not mentioned in the text and are an anonymous conjecture. 


\section{Audiat haec commune solum longeque carinis}

Nota Pharos, flentemque attollens gurgite vultum

Nostra gemat Nilus numerosis funera ripis.

(Claud. c.m. XXII 56-58).

Earlier in this very poem he sums up the exemplum of Alexander's generosity towards enemies, stating: conditor hic patriae; sic hostibus ille pepercit (Claud. c.m. XXII 20), a phrase usually understood as a reference to Alexandria. The last pieces to be noted are two poems to Anicii brothers, Olybrius and Probinus, whom Claudian honoured in his panegyric in $395 \mathrm{AD}$. Addressing Olybrius, the poet calls him sodalis (Claud. c.m. XL 19), which means they were - more or less - peers and we know about Olybrius that he was about 20 when he became a consul. In a distich from carmen to Probinus he states: Romanos bibimus primum te consule fontes / Et Latiae accessit Graia Thalia togae (Claud. c.m. XLI 13-14). This passage contains a clear reference to some kind of a transition between Greek and Latin "element". ' Should we read it as a proof of abandoning Greek letters to write in Latin? It is not so obvious since this phrase puts more emphasis on the end point (official poetry in Latin) than on the starting point, but we actually have some Greek poems of Claudian ${ }^{8}$ which add some probability to such an interpretation.

On the basis of the aforementioned evidence we can stage the following reconstruction: Claudian was born in Egyptian Alexandria about 370-375 AD. He started to write Greek poetry in Egypt, but having come to Italy in about $394 \mathrm{AD}$ he entered the circle of Anicii. At the beginning of $395 \mathrm{AD}$, he delivered a panegyric for young Probinus and Olybrius, his first poem in Latin, and then his career developed, enabling him to become official panegyrist of the new government in the West.

In 1997, this communis opinio was challenged by Peder G. Christiansen. ${ }^{9}$ He negated Egyptian origin of the poet ascribing it to Renaissance scholars who - not having solid information about his biography

$7 \quad$ Different interpretations: Cameron 1970: 458; Mulligan 2007: 299-301; Wheeler 2007: 98; Gualandri 2013: 116.

8 A fragment of "Gigantomachia" and seven epigrams. However, some of them should be attributed to another Claudian, cf. Cameron 1970: 6-19; Focanti 2016.

9 Christiansen 1997. Interestingly, despite Cameron's strong support for Claudian's Egyptian origins, Christiansen did not polemicise with his arguments in favour of it. 
- had tried to reconstruct it on the basis of the available material, using first of all his own poetry. ${ }^{10} \mathrm{He}$ raised the following arguments:

- the theory of Egyptian origin is not based on solid textual evidence but rather should be treated as a conjecture;

- this conjecture is based mainly on Claudian's own poetry which does not take into consideration the difference between the poet himself and the literary persona he created;

- it is hard to imagine that one person could be skilled enough to write poetry in two different language and to do it better in an acquired one than in his mother tongue;

- had Claudian really been an Egyptian, the sources would have made notice of it (argumentum ex silentio).

The weight of these arguments differs significantly from one to another. Christiansen is surely right when he asserts that it is risky to create poets' biographies on the basis of evidence from their own works. Today, such a methodological stance, not distinguishing between the poet himself and the literary persona he creates in his poems, seems obsolete and misleading. Christiansen aptly cited important monograph of M. R. Lefkowitz on the lives of Greek poets, in which she showed how vitae poetarum hinge upon information taken literally from the poems of those authors. ${ }^{11}$ In the case of Claudian, who in accordance with the rules of genre keeps silent about himself in his public poetry, the main source of such internal evidence are his carmina minora: the collection of 52 poems varying in length, subject and meter (G. Luck was surely right calling it disiecta membra). Another problem is our lack of knowledge on chronology and addressees of given pieces: the names written in lemmata usually have no support in the text, so they are only conjectures. Therefore, we must be very careful while making use of these poems. ${ }^{12}$

Christiansen's ideas met with resistance of Bret Mulligan who in his paper from 2007 defended the Eastern (the most probably Egyptian) descent of the poet, treating it as a more convincing option than his Western origin not supported actually by any positive evidence. Mulligan's

\footnotetext{
10 Christiansen (1997: 79-81) mentioned contrary tradition, according to which Claudian came from Italy (from Florence) or Spain.

$11 \quad$ Lefkowitz 2012.

12 On Claudian's carmina minora see esp. Luck 1979; Consolino 2004; Michners 2004; Garambois-Vasquez 2007: 40-61.
} 
polemic is very elegant and incisive, it displays a number of aspects that Christiansen failed to take into account. One of the most important corollaries is the fact that Western origin of the poet lacks solid backing, whereas both external and internal evidence (admittedly, not an obvious one) side with the idea of his Eastern origin. Christiansen's response (in his article from 2009 published in cooperation with David Christiansen) to Mulligan's charges seems to me unconvincing and not referring to the essence of his opponent's arguments, expanding instead on some aspects of Claudian's religious affiliation which actually is not decisive in terms of his descent: both an Egyptian and a Westerner could have been a pagan those days. Although Mulligan has already refuted the majority of Christiansen's argument against the Egyptian connections of the poet, some other points may be further discussed and developed. Let us now turn then to aforementioned passages that refer or at least could possibly refer to Claudian's early years.

The significance of Sidonius' testimony, the earliest external evidence on Claudian's origin, cannot be underestimated. I cannot disagree with Mulligan in terms of his reading of the aforementioned passage. ${ }^{13}$ Christiansen sees it only as an allusion to Lucan (via Statius). ${ }^{14}$ However, the place of this mention in the long catalogue of authors whom Sidonius does not want to imitate in his carmen IX is important for its proper understanding. Not only the reference to Egypt indicates Claudian but also the mention of the poem on marriage and infernal world (1. 275-276), which cannot be understood in any other way than as a poem on marriage between Hades and Proserpina (interestingly, Christiansen omits this lines!). If this phrase should be read as a remark about an Egyptian poet who wrote on the rape of Proserpina, to whom other than Claudian could it refer? If not, why Egypt is alluded at all in such a context? Furthermore, the influence of Claudian on Sidonius is indisputable: Cameron rightly wrote about Claudian's "hypnotic effect" on Sidonius. ${ }^{15}$ The relations between these two poets became a topic of many studies which unanimously show the great extent of Claudian's influence on Sidonius. ${ }^{16}$ Therefore, it would be very strange for the latter not to mention Claudian

\footnotetext{
13 Mulligan 2007: 290-292.

14 Christiansen 1997: 88-89.

15 Cameron 1970: 8.
}

16 See e.g. Schindler 2009: 181-216; Kelly 2013; Gualandri 2020; Babnis 2021. 
in this catalogue. The bishop of Clermont could have been wrong but the mere fact that he treated his great poetic predecessor as an Egyptian is meaningful. The phrase Pelusiaco satus Canopo is an example of the erudite show-off typical of poesis docta and it actually contains geographically improbable juxtaposition of Canopus (town at the outskirts of Alexandria, west of the Nile) and Pelusium (border port of Egypt, east of the Nile). Canopus, mentioned quite frequently in the Latin poetry and known for its luxury (cf. Verg. Georg. IV 287; Luc. X 64; Iuv. XV 46), became a symbol of Egypt in general, so we should treat Sidonius' phrase neither as a reference to Canopus, nor to nearby Alexandria. Employment of such seemingly precise proper names (frequent in Latin poets' references to the world of Orient) is much more a proof of literary erudition than a trustworthy information about geographical location.

Claudian's poem c.m. XIX contains the mention of the Nile called "ours" by the poet. If we are to take the name of Gennadius preserved by the lemma at face value, we could assert that his Syrian origin (cf. Syn. Ep. 73) does not allow to ascribe Claudian's nostro [Nilo] to him. In this case, this juncture can be ascribed only to the poet, being in line with other statements put under scrutiny. Although Egypt was generally considered an interesting and exotic subject by the Graeco-Roman authors, ${ }^{17}$ we can observe a kind of specific fondness for this topic in Claudian's oeuvre. He devoted the whole poem to the Nile (c.m. XXVIII) and to the Phoenix (c.m. XXIX), and displayed the knowledge of some other motifs that may show an impact of Egyptian traditions. ${ }^{18}$ Obviously, the phrase nostro ... Nilo itself is not conclusive but it gains support from similar statement in c.m. XXII, in which the Nile is to mourn the poet's funeral. These two passages make up a basis for the assumption of Claudian's Egyptian origin. In the poem to Hadrianus the poet mentions commune solum as well, which seems to suggest that both persons come from the same place. Christiansen's considerations ${ }^{19}$ on the juxtaposition of c.m. XXI and XXII and the question of identification Pharius (i.e. an Egyptian) from c.m. XXI and Hadrianus known from lemma of c.m. XXII are

\footnotetext{
17 From a great number of studies on this topic see esp. Manolaraki 2013; Tracy 2014.

18 Cf. Coombe 2018: 84, 87, 134 n. 26, 151

19 Christiansen 1997: 83-85. His arguments were partially refuted on the grounds of manuscript tradition by Mulligan (2007: 295-298).
} 
in fact rather irrelevant to the whole issue, since even if Hadrianus was not an Egyptian (commune solum should be read in a different way, e.g. as a reference to the earth or the Roman Empire in general), it does not affect the essential use of the pronoun noster in the context of the Nile, because noster is very often used as a synonym for meus. The combination of information from those two carmina minora displays clearly that Claudian at least wanted to make an impression of personae of both poems sharing Egyptian background.

In Christiansen's argumentation against the Paphlagonian descent of the poet we can find a statement that such a term could be treated metaphorically rather than literally, and that in his opinion the same goes for being an Alexandrian. ${ }^{20}$ This point is worth consideration since the idea of Alexandrian origin (contrary to Egyptian in general) is based on weaker arguments. Actually, the only clear reference to it can be found in Suda. To this we can add the potentially allusive phrase conditor hic patriae (c.m. XXII 20). However, being a Greek poet from Egypt is by no means tantamount to being an Alexandrian. The seminal paper of Alan Cameron has shown that in the Late Antiquity Egypt was a cradle of poets and they usually came from the upper part of the country. ${ }^{21} \mathrm{Un}$ doubtedly, the author of Suda could not have read Cameron's "Wandering Poets" and probably had no knowledge of the activities of a number of Greek poets from Egyptian hinterland, so he might have supposed that Alexandria (even more so because alluded to in one of carmina minora) was the only place from where such a poet could have come from due to its essential place in the history of Greek culture.

Obviously, we cannot rule out the possibility that Claudian spent some time in Alexandria. I would even call it very probable. In regard to other Greek poets from Egypt, Cameron suggested that they could have stay there for educational purposes. ${ }^{22}$ Another reason for visiting Alexandria could have been poetic tournaments attracting wandering poets searching for fame and patrons. ${ }^{23}$ It is possible that Claudian's stay in Alexandria (for whatever reason) or even the fact that he left Egypt sailing

\footnotetext{
$20 \quad$ Christiansen 1997: 88.

21 Cameron 1965; Cameron 1970: 4-6.

22 Fargues 1933: 6-7; Cameron 1970: 5.

23 Lines 11-15 of Claudian's Greek "Gigantomachia" may make up an allusion to such a tournament - Mulligan 2007: 286, n. 7.
} 
out from there paved the way for calling him "Alexandrian" in the tradition preserved by Suda. Sidonian phrase Pelusiaco satus Canopo cannot be treated as an unequivocal reference to Alexandria, though Canopus was almost in its suburbs. This name was widely used as a byword for Egypt. One finds even more problems in Claudian's own words, that is, in the aforementioned line from c.m. XXII: Conditor hic patriae; sic hostibus ille pepercit. This sentence is a summary of previous exemplum of Alexander and Porus but the wording in manuscripts does not make a good sense. Normally, anaphoric pronouns hic and ille should refer to two different persons, ${ }^{24}$ in this case hic to Porus and ille to Alexander. On the other hand, it would be unclear why Porus should be called "the founder of the homeland", so this phrase is usually ascribed to Alexander. Thus a reference to Alexandria is created. Goodyear's conjecture (taken into account in apparatus of Hall's edition): ipse for ille solves the problem, ${ }^{25}$ though it lacks corroboration in manuscripts. Furthermore, even if we accepted it we would not have any information on whose patria was founded by Alexander since Hadrianus' patria could be different from that of Claudian, since - as already noted - the addressee's background is in fact not known. In my view, it would be better to pass over this unclear line in discussion on Claudian's origin and carefully not assume that he really came from Alexandria.

Mulligan rightly pointed out that Christiansen had omitted an important passage from carmen to Probinus (Claud. c.m. XLI 13-14) in which the poet brought up his transition from Graia Thalia to Latia toga (1. 14). If it were not for the existence of "Gigantomachia" and several epigrams ascribed to Claudian in "Anthologia Palatina", we could treat Graia Thalia metaphorically. However, if we have an explicit statement about it in the poem addressed to a public person as Probinus, it cannot be treated this way. Attempts to deny the possibility of Claudian's being an author of at least some of them were unsuccessful in terms of the striking thematic similarity between Latin carmina minora on a crystal ball with water inside and Greek epigrams on the same subject. ${ }^{26}$ Again,

\footnotetext{
24 And always does in Claudian as convincingly shown by Mulligan (2007: 299, n. 52).

25 This conjecture is accepted e.g. by Consolino (2004: 149 n. 28) who rightly notices the problems of - grammatically correct - ascribing hic to Porus.

26 Fargues 1933: 8, n. 4; Cameron 1970: 12-13.
} 
writing Greek poetry is not an equivocal support for the poet's Egyptian origin but surely makes his Eastern background much more probable, especially when we juxtapose it with the aforementioned bilingual inscription. ${ }^{27}$ Christiansen's assertion on the improbability of being a better poet in an acquired language than in the mother tongue ${ }^{28}$ also misses the point, since the great majority of Greek literature of the imperial age did not withstand the test of time and Claudian at the height of his career was surely focused on writing in Latin with the obvious effect on his Greek poetry. Truth be told, the mere fact that anything from the Greek oeuvre of the poet survived is much more surprising (in a positive way) than the lack of his great achievements in the realm of Greek literature. ${ }^{29}$

The issue of language is another Christiansen's argument for western origin of the poet. According to him, Claudian's Latinity is too good and too classical for someone who was not a native speaker of Latin. ${ }^{30} \mathrm{Be}-$ ing a great author in an acquired language is indeed a rare achievement, but it has happened over the centuries. Interestingly, Ammianus Marcellinus was a contemporary parallel to Claudian being another Greek who became an important Latin author, though obviously he must have had daily contact with Latin during his long military service. Claudian's Latinity, both in terms of vocabulary and prosody, was the object of detailed scrutiny. ${ }^{31}$ Scholars put an emphasis on his close acquaintance with earlier Latin poetry, not only with classics like Vergil or Ovid but also with authors of early imperial age, such as Lucan, Statius and Silius Italicus. ${ }^{32}$ According to Christiansen, the fact that Claudian's Latin is so classical and that he showed virtually no influence of contemporary late Latin is

27 More on Greek poetry ascribed to Claudian (or Claudians) see: Cameron 1970: 7-29; Focanti 2016.

28 Christiansen 1997: 86.

29 There are also other explanations for "hiding" the poet's Greek background. Firstly, the need for showing of his Romanness at any price. Secondly, the need to adjust to his audience that in those days was no longer well versed with Greek literature. Gualandri 2013: 116-118.

30 Christiansen 1997: 91-94.

31 See esp. Paucker 1880; Duckworth 1967: 117-124; Ceccarelli 2004; Kruschwitz, Coombe 2016.

$32 \quad$ From a large number of studies on this issue see e.g. Wheeler 2007; Ware 2012; Berlincourt, Milić, Nelis (eds.) 2016. 
another argument against his Egyptian origin. ${ }^{33}$ However, as brilliantly shown by Mulligan, this can prove something opposite ${ }^{34}$ : the acquisition of language usually through reading earlier authors. The obvious problem stemming from it is how a poet from the Eastern part of the Roman Empire could have received such an education, if Latin had not been widely used there and Greek (not Latin) literature had been taught at schools. However, there are some important more or less contemporary Late Antique writers from the East who wrote in Latin, like Ammianus Marcellinus, Priscian of Caesarea or - most certainly - an anonymous author of "Alcestis Barcinonensis". ${ }^{35}$ Their example clearly shows the possibility of receiving a good training in Latin in the East as well. Egypt with its exceptional source material provides us with a lot of evidence regarding language mosaic of this province and Latin's place in it. ${ }^{36}$

Disputing with Mulligan's argument on the possibilities of receiving a good Latin education in Egypt, Christiansen and Christiansen point out that there is no sign of teaching of other Latin poets than Vergil in this part of the Empire. ${ }^{37}$ Yet Egyptian descent is not tantamount to receiving education only in Egypt, especially when we consider the great mobility of Late Antique authors, scholars and students. ${ }^{38}$ Scholars have already suggested the possibilities of Claudian's travels in the Roman East and even if the information of patria ascribed to him by Suda is not to be taken at face value, his contacts with other cultural centres in the eastern provinces have to be at least taken into consideration. The detailed study of the Latin-speaking environment of Constantinople in the $4^{\text {th }}$ century carried out by Maciej Salamon ${ }^{39}$ shows that the eastern capital was an important, or even the most important centre of Latin culture in the East. This historian agrees with the opinion of Alan Cameron that Claudian

\footnotetext{
33 Christiansen 1997: 94.

$34 \quad$ Mulligan 2007: 304.

35 Cf. Fargues 1933: 6; Geiger 1996.

36 See e.g. Bagnall 1993: 231-234; Adams 2004: 527-641; Cribiore 2007 (esp. 57-63).

37 Christiansen, Christiansen 2009: 138. However, Cribiore (2007: 60-61) mentions also Cicero, Juvenal, Sallust and Terence and writes about a greater demand for bilingual Greek-Latin texts in the $4^{\text {th }}$ century AD.

38 Cribiore 2007: 55-57.

39 Salamon 1977.
} 
could have visited Constantinople. ${ }^{40}$ In my judgement, this observation has not been fully appreciated so far. Not only might Claudian's stay in Constantinople be seen as a possibility of acquiring to a greater extent the knowledge of Latin language and poetry, ${ }^{41}$ but also as an occasion for his earlier meeting with Stilicho. ${ }^{42}$ Thus Claudian's acquaintance with his future patron could have been longer and his contacts with imperial elites could have started earlier.

The panegyric on Probinus and Olybrius does not contain the slightest mention of Stilicho, and this fact has usually been seen to date as a reason for lack of the earlier contact between the poet and the circle of people connected with Theodosius. However, before the death of the emperor, Stilicho (taken by his ruler and father-in-law to the West in a campaign against Eugenius) was not as important a person as he suddenly became after 17 January 395 AD, especially in Italy, just reconquered from the usurper. One should not perceive Claudian's first panegyric from the perspective of his poetry from later years when he was to become an official propagandist of the Honorius' court. Therefore, the lack of references to Stilicho is nothing strange, since he was not as significant yet as he was to become soon. With Theodosius still alive, the need of regency for 10-years-old Honorius was not a pressing problem, particularly if we juxtapose it with the urgent need of reconciliation with the Italian aristocracy. Cameron has suggested some backing from powerful friends received by Claudian at the very beginning of his career

40 Cameron 1970: 26-28; Salamon 1977: 99. Constantinople in the poetry of Claudian: Cameron 1970: 366-369; Long 2004: 14-15; Kelly 2012.

41 We cannot treat literally the phrase from c.m. XLI that the panegyric on Probinus and Olybrius was the first piece written by Claudian in Latin. It could have been the first serious public poem he delivered but the quality of the poem obviously shows that he must have had a lot of earlier practice in the sphere of Latin poetry - Cameron 1970: 458; Gualandri 2013: 115. These works are not known to us, however Constantinople could have been a suitable place for developing literary skills.

42 The Eastern origin of Stilicho seems to go unnoticed by scholars, who focus on his later career in the West and his aggressive policy towards Constantinople and his regents (esp. Rufinus and Eutropius). However, the reasons of such a policy stemmed obviously from his desire for extending his power to the weak Arcadius, not from the contempt for the East or from "Orientalist" mindset. Of course, a number of anti-Oriental stereotypes were used in the poetry of Claudian, especially in his invective against Eutropius. See e.g. Babnis 2020. 
in the West. This seems necessary, but the poet could have been given support not only from the Western elites but also from the ruling circles connected with Theodosius to which he was already known.

Naturally, one cannot say for certain when precisely Claudian came to Italy. One possibility is $394 \mathrm{AD}$, which would mean that he came only with the Eastern armies. ${ }^{43}$ Such a late date however would give him little time to become acquainted with the elites of the Western Empire. Yet the earlier arrival would be more probable as it would give Claudian more time to perfect his Latin and come in contact with local aristocracy, especially the Anicii, since due to his employment of the word sodalis (c.m. XL 19) the relation with Olybrius should be understood as more intimate. These double connections, both with Italian elites and ruling circles of the East, could be seen as essential factors in Claudian's career. What is more, they were complementary to each other since Anicii brothers ought to be seen as people trusted by the emperor, as he granted them consulship. In the context of Theodosius' reconciliation with Italian aristocracy, the rise of Claudian can be perceived as natural and stemming from his earlier activities.

Christiansens' assumption that the poet as a pagan was earlier active on Eugenius' side ${ }^{44}$ is unduly influenced by the idea of a religious character of the conflict in 394 AD. Therefore, they suppose that Augustine and Orosius clearly treat the poet as a supporter of the usurper which cannot be discerned in their statements. Yet Cameron's detailed scrutiny of sources referring to the battle of the Frigidus has shown that such an interpretation was created by $5^{\text {th }}$-century ecclesiastical historians (Rufinus of Aquileia in particular). ${ }^{45}$ Obviously, there were pagans on Eugenius' side (as there were among his opponents) and Theodosius had to reach an agreement with them, but it was not religion that was the main problem in reconciliation after the battle of the Frigidus. That being so, the religious affiliation of Claudian is still unknown and it cannot be a base to solve the issue of his origin. However, it does not change the fact that his contacts with Western aristocracy are a crucial factor in the discussion on his poetic career.

\footnotetext{
$43 \quad$ As suggested by Fargues (1933: 10).

44 Christiansen, Christiansen 2009: 139-141.

45 Cameron 2011: 93-131.
} 
In his poetry Claudian included hardly anything about his biography. Rare pieces of information can be found only in his carmina minora, whereas external evidence is also scarce and not always trustworthy. The tenor of relevant passages seems to suggest that Claudian was really an Egyptian Greek by birth and almost certainly an Easterner and even if the evidence for this is not watertight, I must agree with Alan Cameron and Bret Mulligan that it is nevertheless stronger than the case for his western origin made by Peder G. Christiansen, especially in the face of his strange omissions of some passages being at variance with his thesis.

Equating the poetical persona with the poet himself is indeed risky, but the aforementioned lines from Claudian's carmina minora suggest that the poet wanted his audience to treat him as a native of Egypt. Lack of geographic precision in the passage of Sidonius, typical of ancient poesis docta in general, is obvious, but nevertheless the phrase Pelusiaco satus Canopo can be understood as a clear-cut reference to Egypt. However, the reference to Alexandrian origin in Suda ought to be treated with caution since any evidence that the poet actually came from this very city is much weaker than the one pointing to him being a Greek from Egypt. On the other hand, the poet's stay in Alexandria (as a centre of learning and a seat of potential patrons) can be assumed with much more certainty. On the whole, the evidence creates a kind of a network of mutual connections suggesting the poet's Eastern origin.

Claudian should be seen in the context of Late Antique "wandering poets" active in different centres of the Roman Empire and frequently moving from one place to another. This concept is in line with Claudian's Egyptian descent and can easily explain his arrival in Italy. Basing on Maciej Salamon study on the role of Constantinople as the centre of the Latin culture in the Roman East, I would like to suggest the great probability of Claudian having spent some time there. This could be an explanation of his great knowledge of Latin language and literature (acquisition of which to such an extent in Egypt would be hard to imagine) as well as his contacts with the ruling circles of Constantinople. Seen in this context, Claudian's early career in Italy, especially his "promotion" to the position of court spokesman or even propagandist after delivering the panegyric for Probinus and Olybrius, can be better understood as a result of his double connections both with Western aristocracy and with the environment of Theodosius from which Stilicho was about to 
come to the fore soon. The problem of Claudian's religious affiliation seems to be insoluble, but it cannot either prove or disprove the poet's Egyptian descent. One should hope that future will bring some new evidence that could expand our knowledge of Claudian's biography solving mysteries we face today. In this respect, especially Egypt, the homeland of the poet, could contribute the most to corroborate its "right" to this great author.

\section{REFERENCES}

\section{Primary sources}

Claudian, Vol. I-II, ed., trans. M. Platnauer, Cambridge - London 1963.

Claudianus, Carmina, ed. J. B. Hall, Leipzig 1985.

Ioannes Lydus, On Powers or The Magistracies of the Roman States, ed., trans. A. C. Bandy, Philadelphia 1983.

Sidonius, Poems and Letters, Vol. I: Poems, Letters, Books I-II, ed., trans. W. B. Anderson, Cambridge - London 1963.

\section{Secondary sources}

Adams J. N., 2004, Bilingualism and the Latin Language, Cambridge. https://doi. org/10.1017/CBO9780511482960.

von Albrecht M., 1997, A History of Roman Literature. From Livius Andronicus to Boethius, Leiden - New York - Köln. https://doi.org/10.1163/9789004329904.

Babnis T., 2020, 'Eutropius as an Oriental. Building the Invective with References to Orient in the First Book of Claudian's In Eutropium', Classica Cracoviensia 23, pp. 7-23. https://doi.org/10.12797/CC.23.2020.23.01.

Babnis T., 2021, 'Idem aliter, czyli o dwóch opisach dyplomatycznej podróży do Persji w poezji późnego antyku (Claud. Cons. Stil. I 51-68; Sid. Carm. II 75-88)', Collectanea Philologica 24, pp. 111-125, https://doi. org/10.18778/1733-0319.24.07.

Bagnall R., 1993, Egypt in Late Antiquity, Princeton.

Berlincourt V., Milić L. G., Nelis D. (eds.), 2016, Lucan and Claudian: Context and Intertext, Heidelberg.

Cameron A., 1965, 'Wandering Poets. A Literary Movement in Byzantine Egypt', Historia: Zeitschrift für Alte Geschichte 14/4, 470-509. 
Cameron A., 1970, Claudian. Poetry and Propaganda at the Court of Honorius, Oxford.

Cameron A., 2011, The Last Pagans of Rome, Oxford. https://doi.org/10.1093/ acprof:oso/9780199747276.001.0001.

Ceccarelli L., 2004, 'Osservazioni sull'esametro di Claudiano', [in:] Aetas Claudianea. Eine Tagung an der Freien Universität Berlin vom 28. bis 30. Juni 2002, W.-W. Ehlers, F. Felgentreu, S. Wheeler (eds.), München - Leipzig, pp. 104-141. https://doi.org/10.1515/9783110928846.104.

Christiansen P. G., 1997, ‘Claudian. A Greek or a Latin?’, Scholia 6, pp. 79-95.

Christiansen P. G., Christiansen D., 2009, 'Claudian. The Last Great Pagan Poet', L'Antiquité Classique 78, pp. 133-144. https://doi.org/10.3406/ antiq.2009.3741.

Consolino F. E., 2004, 'Poetry and Politics in Claudian's carmina minora 22 and 20', [in:] Aetas Claudianea. Eine Tagung an der Freien Universität Berlin vom 28. bis 30. Juni 2002, W.-W. Ehlers, F. Felgentreu, S. Wheeler (eds.), München - Leipzig, pp. 142-174. https://doi.org/10.1515/9783110928846.142.

Coombe C., 2018, Claudian the Poet, Cambridge. https://doi. org/10.1017/9781107415645.

Cribiore R., 2007, 'Higher Education in Early Byzantine Egypt. Rhetoric, Latin and the Law', [in:] Egypt in the Byzantine World, 300-700, R. S. Bagnall (ed.), Cambridge, pp. 47-66.

Cytowska M., Szelest H., 1992, Literatura rzymska. Okres Cesarstwa, Warszawa.

Döpp S., 1980, Zeitgeschichte in Dichtungen Claudians, Wiesbaden.

Duckworth G. E., 1967, 'Five Centuries of Latin Hexameter Poetry. Silver Age and Late Empire', Transactions and Proceedings of the American Philological Association 98, pp. 77-150. https://doi.org/10.2307/2935870.

Ehlers W.-W., Felgentreu F., Wheeler S. (eds.), 2004, Aetas Claudianea. Eine Tagung an der Freien Universität Berlin vom 28. bis 30. Juni 2002, München Leipzig. https://doi.org/10.1515/9783110928846.

Fargues P., 1933, Claudien. Études sur sa poésie et son temps, Paris.

Focanti L., 2016, 'The patria of Claudianus (FGrHist 282)', Greek, Roman, and Byzantine Studies 56, pp. 485-503.

Garambois-Vasquez F., 2007, Les invectives de Claudien. Une poétique de la violence, Bruxelles.

Geiger J., 1999, 'Some Latin Authors from the Greek East', The Classical Quarterly 49/2, pp. 606-617. https://doi.org/10.1093/cq/49.2.606. 
Gualandri I., 2013, 'Claudian from Easterner to Westerner', Talanta 45, pp. $115-129$.

Gualandri I., 2020, 'Sidonius' Intertextuality', [in:] The Edinburgh Companion to Sidonius Apollinaris, G. Kelly, J. A. van Waarden (eds.), Edinburgh, pp. 279-316.

Guipponi-Gineste M.-F., 2010, Claudien. Poète du monde à la cour d'Occident, Paris.

Kelly G., 2012, 'Claudian and Constantinople', [in:] Two Romes. Rome and Constantinople in Late Antiquity, L. Grig, G. Kelly (eds.), Oxford, pp. 241-264.

Kelly G., 2013, 'Sidonius and Claudian', [in:] New Approaches to Sidonius Apollinaris, J. A. van Waarden, G. Kelly (eds.), Leuven - Paris - Walpole, pp. 171194. https://doi.org/10.1093/acprof:oso/9780199739400.003.0011.

Kruschwitz P., Coombe C., 2016, 'I, Claudian. The Syntactical and Metrical Alignment of Ego in Claudian and His Epic Predecessors', Journal of Latin Linguistic 15/1, pp. 73-115.

Lefkowitz M. R., 2012, The Lives of the Greek Poets, Baltimore. https://doi. org/10.1515/joll-2016-0003.

Long J., 1996, Claudian's In Eutropium. Or, How, When, and Why to Slander a Eunuch, Chapel Hill - London.

Long J., 2004, 'Claudian and the City. Poetry and Pride of Place', [in:] Aetas Claudianea. Eine Tagung an der Freien Universität Berlin vom 28. bis 30. Juni 2002, W.-W. Ehlers, F. Felgentreu, S. Wheeler (eds.), München - Leipzig, pp. 1-15. https://doi.org/10.1515/9783110928846.1.

Luck G., 1979, “'Disiecta Membra”. On the Arrangement of Claudian's “Carmina minora”, Illinois Classical Studies 4, pp. 200-213.

Manolaraki E., 2013, Noscendi Nilum Cupido. Imagining Egypt from Lucan to Philostratus, Berlin - Boston. https://doi.org/10.1515/9783110297737.

Michners J., 2004, 'Spott und Ironie in Claudians carmina minora', [in:] Aetas Claudianea. Eine Tagung an der Freien Universität Berlin vom 28. bis 30. Juni 2002, W.-W. Ehlers, F. Felgentreu, S. Wheeler (eds.), München - Leipzig, pp. 175-186. https://doi.org/10.1515/9783110928846.175.

Moreschini C., 2004, 'Paganus pervicacissimus. Religione e "filosofia" in Claudiano', [in:] Aetas Claudianea. Eine Tagung an der Freien Universität Berlin vom 28. bis 30. Juni 2002, W.-W. Ehlers, F. Felgentreu, S. Wheeler (eds.), München - Leipzig, pp. 57-77. https://doi.org/10.1515/9783110928846.57.

Mulligan B., 2007, 'The Poet from Egypt? Reconsidering Claudian's Eastern Origin', Philologus 151/2, pp. 285-310. https://doi.org/10.1524/phil.2007.0006. 
Paucker C., 1880, 'De latinitate Claudiani poetae observationes', Rheinisches Museum für Philologie 35, pp. 586-606.

Salamon M., 1977, Środowisko kultury łacińskiej w Konstantynopolu w IV wieku, Katowice.

Schamp J., 2001, 'Claudien le «Paphlagonien», poète d'Alexandrie', Latomus 60/4, pp. 971-991.

Schindler C., 2009, Per carmina laudes. Untersuchungen zur spätantiken Verspanegyrik von Claudian bis Coripp, Berlin - New York. https://doi. org/10.1515/9783110210583.

Schmidt P. L., 1976, Politik und Dichtung in der Panegyrik Claudians, Konstanz.

Tracy J., 2014, Lucan's Egyptian Civil War, Cambridge. https://doi.org/10.1017/ CBO9781139680332.

Vanderspoel J., 1986, 'Claudian, Christ and the Cult of the Saints', The Classical Quarterly 36/1, pp. 244-255. https://doi.org/10.1017/S0009838800010697.

Ware C., 2012, Claudian and the Roman Epic Tradition, Cambridge. https://doi. org/10.1017/CBO9781139004152.

Wheeler S., 2007, 'More Roman than the Romans of Rome. Virgilian (Self-)Fashioning in Claudian's Panegyric for the Consuls Olybrius and Probinus', [in:] Texts and Culture in Late Antiquity. Inheritance, Authority, and Change, J. H. D. Scourfield (ed.), Swansea, pp. 97-133. 